\begin{tabular}{|c|l|}
\hline Title & $\begin{array}{l}\text { Changes in the plasma levels of insulin-like growth factor-I from the onset of spawning migration through upstream } \\
\text { migration in chum sal mon }\end{array}$ \\
\hline Author(s) & $\begin{array}{l}\text { Onuma, Takeshi A.; Makino, Keita; Katsumata, Hiroshi; Beckman, Brian R.; Ban, Masatoshi; A ndo, Hironori; } \\
\text { Fukuwaka, Masa aki; A zumay a, Tomonori; Swanson, Penny; Urano, A kihisa }\end{array}$ \\
\hline Citation & $\begin{array}{l}\text { General and Comparative Endocrinology, 165(2), 237-243 } \\
\text { https://doi.org/10.1016/.ygcen.2009.07.005 }\end{array}$ \\
\hline Issue Date & 2010-01-15 \\
\hline Doc URL & http://hdl.handle.net/2115/42619 \\
\hline Type & article (author version) \\
\hline File Information & GCE165-2_237-243.pdf \\
\hline
\end{tabular}

Instructions for use 
General and Comparative Endocrinology (2 ${ }^{\text {nd }}$ revision)

\section{Changes in the plasma levels of insulin-like growth factor-I from the onset of spawning migration through upstream migration in chum salmon}

Takeshi A. Onuma ${ }^{1-2)}$, Keita Makino ${ }^{2)}$, Hiroshi Katsumata ${ }^{2)}$, Brian R. Beckman ${ }^{3)}$, Masatoshi Ban 4), Hironori Ando ${ }^{1)}$, Masa-aki Fukuwaka 5), Tomonori Azumaya 5), Penny Swanson ${ }^{3)}$ and Akihisa Urano ${ }^{2)}$

${ }^{1}$ Graduate School of Bioresource and Bioenvironmental Sciences, Kyushu University, Fukuoka 812-8581, Japan, ${ }^{2}$ Section of Biological Sciences, Graduate School of Life Sciences, Hokkaido University, Sapporo 060-0810, Japan, ${ }^{3}$ Northwest Fisheries Science Center, NOAA Fisheries, Seattle, WA, 99164, USA, ${ }^{4}$ National Salmon Resources Center, Fisheries Research Agency, Sapporo 062-0922, Japan, ${ }^{5}$ Hokkaido National Fisheries Research Institute, Fisheries Research Agency, Kushiro 085-0802, Japan.

[Abbreviated title] IGF-I and salmon migration

[Address all correspondence and reprint request] Takeshi A. Onuma, Graduate School of Bioresource and Bioenvironmental Sciences, Kyushu University, Fukuoka 812-8581, Japan.

Present address: Molecular, Cellular, and Developmental Biology, University of Michigan 830 N. University, Ann Arbor, MI 48105.

Phone: +1-734-929-7372, E-mail: takeshikiai@msn.com

[Keywords] spawning migration; chum salmon; growth; IGF-I; liver; gonad; gonadotropin; androgen; estrogen; pituitary-gonadal axis

[Number of text pages] $19 \quad$ [Number of figures] 3 [Number of tables] 2 


\begin{abstract}
An increase in activity of the pituitary-gonadal axis (PG-axis) and gonadal development are essential for the onset of spawning migration of chum salmon from the Bering Sea. In the Bering Sea, fish with larger body sizes initiated gonadal development and commenced spawning migration to the natal river by the end of summer. We thus hypothesized that insulin-like growth factor-I (IGF-I), a somatotropic signal that interacts with the PG-axis, can be one of such factors responsible for the onset of migration, and examined changes in plasma levels and hepatic expression of IGF-I gene in oceanic and homing chum salmon in 2001, 2002 and 2003. The plasma IGF-I levels and corresponding body sizes in maturing adults, which had developing gonads, were significantly higher than those in immature fish in all years examined. Such increase in the plasma IGF-I levels in maturing fish was observed even in the Gulf of Alaska during February 2006, while coincident increase was not observed in the hepatic amounts of IGF-I mRNA. In autumn, the plasma IGF-I levels in homing adults decreased during upstream migration in the Ishikari River-Ishikari bay water system in Hokkaido, Japan. In conclusion, the plasma IGF-I levels increased with gonadal development when chum salmon migrated from the winter Gulf of Alaska to the summer Bering Sea. Circulating IGF-I may interact with the PG-axis and promote gonadal development that is inseparable from the onset of spawning migration. Circulating IGF-I levels were thereafter lowered in accordance with final maturation during upstream migration in the breeding season.
\end{abstract}




\section{Introduction}

We recently reported that the elevation of activity of the pituitary-gonadal axis (PG-axis) and resulting gonadal development are important endocrine events, which occur coincidently with the onset of spawning migration of chum salmon from the summer Bering Sea (Onuma et al., 2009a). These events are triggered more than 6 months prior to the spawning period in autumn, because maturing adults which had developing gonads were seen even in the Gulf of Alaska in February. However, we have few information about humoral factors which interact with the PG-axis and enable oceanic chum salmon to initiate gonadal development.

The previous studies in salmonid reproduction established that the plasma levels of insulin-like growth factor I (IGF-I), a liver polypeptide that acts as a mediator of growth-promoting action of growth hormone (GH) in teleost fishes (Duan and Hirano, 1992), are increased with body growth during winter and spring, and the seasonal increase in circulating IGF-I was linked to initiation of gametogenesis in male chinook salmon (Campbell et al., 2003) and female coho salmon (Campbell et al., 2006). We thus hypothesized that IGF-I might be involved in reproductive maturation of oceanic chum salmon. Indeed, our preliminary investigation indicated that the plasma IGF-I levels in the maturing chum salmon were significantly higher than those in the immature fish in the summer Bering Sea in 2003 and winter Gulf of Alaska in 2006 (Onuma et al., 2009b). In the present study, we thus collected data from chum salmon in 2001, 2002, 2003 and 2006 to provide reproducible or generalizable information on changes in the IGF-I levels around the onset of spawning migration.

In homing chum salmon, activity of the hypothalamus-pituitary-gonadal axis (HPG-axis) increased during upstream migration from the coast through the natal hatchery (Onuma et al., 2003a; Onuma et al., 2005b). In masu salmon, IGF-I 
modulated the amounts of gonadotropin (GTH) subunit mRNAs and release of follicle-stimulating hormone (FSH) and luteinizing hormone ( $\mathrm{LH})$ in pituitary cells by season- and reproductive stage-dependent manners (Ando et al., 2006, Furukuma et al., 2008). These results indicate necessity to clarify changes in the levels of IGF-I during upstream migration of chum salmon, although little information is available on the levels of IGF-I during the final phase of spawning migration.

In the present study, we therefore examined the plasma IGF-I levels and the amounts of IGF-I mRNA in the livers, the major source of circulating IGF-I, in the chum salmon samples that were previously collected along the presumed pathway of spawning migration of Japanese population (Onuma et al., 2009a). The sampling locations included the winter Gulf of Alaska, the summer Bering Sea and also homing pathway in the Ishikari River-Ishikari bay water system in Hokkaido, Japan in the spawning period in autumn. The present study thus enabled us to obtain comprehensive information on profiles of changes in circulating IGF-I levels prior to and during spawning migration. A portion of data from the oceanic fish in 2003 and 2006 was published elsewhere as a preliminary report (Onuma et al., 2009b).

\section{Materials and Methods}

Oceanic and homing chum salmon

Chum salmon, Oncorhynchus keta Walbaum, were caught in the central Bering Sea in summer and autumn from 2001 to 2003, and in the Gulf of Alaska in winter in 2006. The fishing methods and locations of fishing stations are described in our previous report (Onuma et al., 2009a). Chum salmon in the Bering Sea form mixed populations whose stocks originate in the North Pacific Rim. Analyses of 
mitochondrial DNA (mtDNA) haplotypes showed that a considerable portion of chum salmon in these areas belongs to Japanese populations (Moriya et al., 2007; Sato et al., 2006; Sato et al., 2007).

The oceanic chum salmon used in the present study was previously grouped as immature, maturing adult I and maturing adult II by histological diagnosis of gonads (Onuma et al., 2009a). Activity of the PG-axis in the same fish was previously assessed from the absolute amounts of glycoprotein (GP) $\alpha 2$, FSH $\beta$ and LH $\beta$ mRNAs in the pituitary, the pituitary contents of FSH and LH, and the plasma levels of FSH, testosterone (T), 11-ketotestosterone (11KT) and estradiol-17 $\beta$ (E2) (Onuma et al., 2009a).

In the spawning period in autumn, homing adults were captured along their migratory route in the Ishikari River-Ishikari bay water system in Hokkaido, Japan. They are the same fish used in Onuma et al. (2009a). In brief, fish were caught at Esashi along the northeast (NE) coast of Hokkaido in the Sea of Okhotsk, in the Ishikari bay, estuary in the river mouth, the midway point of upstream migration located at the junction of the mainstream of the Ishikari River and the Chitose River, upstream point at $4 \mathrm{~km}$ downstream of the hatchery, and the natal hatchery in the Chitose Field Station (See Onuma et al., 2009a).

\section{Tissue sampling}

All sampling procedures were carried out under the guideline of animal care of Hokkaido University. Folk length (FL) and body weight (BW) were measured, and blood samples were collected from the caudal vasculature to obtain plasma for hormone assays. A portion of the livers was collected and frozen in liquid nitrogen and stored at $-80^{\circ} \mathrm{C}$ until total RNA was extracted. The pituitaries were collected to determine the 
amounts of GTH subunit mRNAs and GTHs (Onuma et al., 2009a). The gonads were removed and weighed to calculate gonadosomatic indices (GSI, gonad weight/body weight $x$ 100). A portion of the testes and ovaries were fixed and stored for later histological analyses. All samples used in the present study are from the same fish in our previous reports (Onuma et al., 2009a; Onuma et al., 2009b).

Radioimmunoassay for determination of the plasma level of IGF-I

Plasma IGF-I levels were measured by radioimmunoassay that is previously established (Shimizu et al., 2000). Specificity was confirmed previously by Shimizu et al. (2000), and sensitivity of the assay was usually $0.3 \mathrm{ng} / \mathrm{tube}$. The range of intra-assay coefficients of variations (CV) was 3.5-10.1\%, and inter assay CV was $13.0 \%$.

Quantitative real-time PCR assays of IGF-I mRNA

Gene expression for IGF-I in the liver was assessed by quantification of the absolute amount of IGF-I mRNA. We utilized the established protocol in which cDNA transcribed from the known number of copies of single-stranded RNA was used to describe a standard curve (Onuma et al., 2005a; Onuma et al., 2007). The sequences of primers were 5'-TCACGGCGGTCACATAACC-3' (forward) and 5'-CCTGTCAAGTCTGGCAAGGC-3' (reverse), and that of the fluorogenic probe was 5’-(Fam)-AGTGCTGCTTCCAGAG TTGCGAGCT-(Tamra)-3’ (TaqMan probe, PE Applied Biosystems). The PCR mixture $(10 \mu \mathrm{l})$ contained $300 \mathrm{nM}$ of each forward and reverse primers and $50 \mathrm{nM}$ of fluorogenic probe. Amplification was carried out at $95^{\circ} \mathrm{C}$ for $10 \mathrm{~min}$, for 40 cycles at $95^{\circ} \mathrm{C}$ for $15 \mathrm{sec}$, and $60^{\circ} \mathrm{C}$ for $1 \mathrm{~min}$.

In each assay, a standard sample (4 ng of masu salmon liver cDNA) was 
subjected to amplification in triplicate to estimate CVs. The ranges of intra-assay CVs were $3.19-13.2 \%$, and the inter assay CV was $14.9 \%$. We confirmed that the single specific fragment was amplified, and the curves obtained from serially diluted liver cDNA were parallel to the standard curves within the ranges between $2 \times 10^{3}$ and $2 \mathrm{x}$ $10^{7}$ copies/well (data not shown).

\section{Statistics}

Values were shown as mean \pm standard error of the mean. One or two abnormal values were removed from each group using Smirnov-Grubb’s test, when significant. The amount of IGF-I mRNA was calculated as copies/ $\mu$ g total RNA. Data from different sampling stations, ages, and mtDNA haplotypes were combined and treated as immature fish or maturing adults as described in Onuma et al. (2009a). One-way ANOVAs followed by a post-hoc Tukey’s test was used to test for statistically significant differences among groups and sampling points. Correlations between the plasma IGF-I levels and the parameters of the PG-axis activity were analyzed by Pearson's correlation test $(\mathrm{p}<0.05$ and 0.01$)$.

\section{Results}

Relationship between body size and gonadal development in oceanic chum salmon

Chum salmon in the Bering Sea were a mixture of immature fish and maturing adults in June and July (Onuma et al., 2009a). Gonadal development was started more than 6 months prior to the spawning period in autumn, because about $30 \%$ of the males and $45 \%$ of the females were maturing adult I fish in the Gulf of Alaska in February 2006. The maturing adults apparently left the Bering Sea for the natal river, because 
almost all fish were absolutely immature in September.

Body size of these oceanic chum salmon was interrelated with initiation of spawning migration from the Bering Sea. The frequency distribution showed that the BW of 3- and 4-year old chum salmon in the Bering Sea widely ranged from 1 to $5 \mathrm{~kg}$ in June and July (Fig. 1, upper panel). They showed multiple skewed components and medians. In September, however, almost all 3-year-old fish were less than $3 \mathrm{~kg}$, and 4-year-old fish were rarely found (Fig. 1, lower panel). Similar seasonal differences were observed in FL (data not shown). In terms of gonadal maturity, the maturing adults showed larger FL and BW when compared with the immature fish in all years examined (Onuma et al., 2009a; Onuma et al., 2009b). Fish with larger body sizes were thus considered to be the maturing adults which initiated homing behavior to the natal river by the end of summer.

The plasma IGF-I levels were coincidently increased in the maturing adults with activity of the PG-axis

The plasma IGF-I level, an established parameter reflecting the growth rate and body size of immature and maturing salmonids, varied depending on the reproductive stages. In the Bering Sea, the plasma IGF-I levels in the maturing adults were significantly higher than those in the immature fish in June and July in 2001, 2002 and 2003 (Table 1). The maturing fish that had higher plasma IGF-I levels were observed in both the 3- and 4-year-old fish (data not shown). Such increase in the plasma IGF-I levels in the maturing adults was initiated even in the Gulf of Alaska in February, although the magnitude of increase in the winter fish was lower than that in the maturing adults in the summer Bering Sea (Fig 2).

The amounts of IGF-I mRNA in the livers of maturing adults, however, did not 
show coincident increase with the plasma IGF-I levels. The amounts of IGF-I mRNA did not differ noticeably between the immature fish and the maturing adult $\mathrm{I}$ in the Bering Sea (Table 1), although those in the maturing females were higher than those in the immature fish in the winter Gulf of Alaska (Fig. 2).

There were positive correlations between the plasma IGF-I levels and the parameters of the PG-axis activity of chum salmon in the summer Bering Sea (Table 2). The plasma IGF-I levels correlated positively $(\mathrm{p}<0.05$ ) with the GSI, pituitary contents of FSH and the plasma levels of FSH and T and 11KT in the 3- and 4-year-olf males. Similarly, the plasma IGF-I levels correlated with the pituitary contents of FSH and the plasma levels of FSH and E2 in the 3-year-olf females, although such positive correlation was not found in the 4-year-old females. The positive correlation was found in both mtDNA haplotype clade A, i.e., Japanese population, and clade B, i.e., mixture of Japanese, Russian and North American populations, particularly in the FSH contents in both sexes, the plasma 11KT levels in the males and the plasma E2 levels in the females. Similar positive correlations were also observed in the winter fish in the Gulf of Alaska (Onuma et al., 2009b). In contrast, the amounts of IGF-I mRNA did not show apparent correlation with the parameters of the PG-axis activity.

Changes in the plasma IGF-I levels and the amounts of hepatic IGF-I mRNA in homing adults

In the homing adults, the plasma IGF-I levels decreased during upstream migration in the natal Ishikari River in all years examined (Fig. 3). The IGF-I levels in the matured adults captured at or near the hatchery were significantly lower when compared to those in the pre-spawning fish at the coastal areas. The plasma IGF-I levels decreased correspondently with final maturation, because all of the present fish 
completed spermiation or ovulation at or near the hatchery (Onuma et al., 2009a). The amounts of IGF-I mRNA decreased significantly during upstream migration from the coast to the point near the hatchery (Fig. 3). Afterward, they increased 2- to 3-fold those in the matured fish at the natal hatchery. Such increase was similarly observed in both 2002 and 2003.

\section{Discussion}

The present results showed that, in oceanic chum salmon, the plasma IGF-I levels in the maturing adults were higher than those in the immature fish in all years examined. Since the maturing adults left the Bering Sea for the natal river by the end of summer (Onuma et al., 2009a), an increase in circulating level of IGF-I is considered as a general endocrine event that is inseparable from the initiation of spawning migration from the Bering Sea. Furthermore, the present study showed that the plasma IGF-I levels decreased during upstream migration to the natal hatchery, where all homing adults completed final maturation.

The frequency distribution of BW showed that oceanic chum salmon with larger body sizes initiated spawning migration to the natal river. This result coincides well with the report by Morita and Fukuwaka (2006). They estimated growth history from annuli of scales in hatchery-arrived chum salmon, and showed that the recent growth rate is the most important factor for oceanic fish to determine whether mature or not mature in the subsequent spawning period. Since the plasma levels of IGF-I correlated well with the growth rates and body sizes in immature and early maturing salmonids (Beckman et al., 1998; Shimizu et al., 2000; Campbell et al., 2003; Campbell et al., 2006), the plasma IGF-I levels may be an important somatotropic signal that interrelated 
with the onset of spawning migration.

The present results support the hypothesis that an increase in circulating IGF-I promotes gonadal development of oceanic chum salmon. In this sense, IGF-I is regarded as a cause and gonadal development as an effect. However, the reverse is also plausible because gonadal steroid hormones changed plasma IGF-I levels (Larsen et al., 2004; McCormick et al., 2005). Changes in circulating levels of IGF-I in homing chum salmon should be actually the consequence of interaction between somatic growth and gonadal development.

The amounts of IGF-I mRNA in the livers of maturing adults did not show correspondent increase with the plasma IGF-I levels, although IGF-I is considered to be released primarily from the liver under the influence of GH even in teleost fishes (Duan and Hirano, 1992). A possible explanation for this discrepancy is that gonads themselves influence circulating IGF-I levels, because the gonads are suggested to be one of the sources of IGF-I (Le Gac et al., 1996; Campbell et al., 2006), and actually express GH receptors (Fukada et al., 2005). The role of developing gonads in IGF-I secretion remains to be clarified.

The plasma IGF-I levels correlated positively with the parameters of the PG-axis activity of the oceanic fish. An abundance of evidence in aquacultured salmonid species established the importance of IGF-I in regulation of syntheses and releases of FSH and LH in the pituitary during the early phases of gametogenesis (Weil et al., 1999; Baker et al., 2000; Ando et al., 2006; Furukuma et al., 2008). In addition, IGF-I directly stimulated steroidogenesis in the salmonid gonads (Maestro et al., 1997). Behaviorally, implantation of $\mathrm{T}, 11 \mathrm{KT}$ and E2 induced migratory behavior of masu salmon (Munakata et al., 2001). We therefore speculate that circulating IGF-I elevated activity of the PG-axis of oceanic chum salmon, and in turn the released sex steroid 
hormones acted on the brain to commence migratory behavior.

The decrease in the plasma levels of IGF-I in the homing adults probably occurred together with the increase in activity of the HPG-axis, because the amounts of salmon gonadotropin-releasing hormone mRNAs in the forebrain and those of LH $\beta$ mRNA in the pituitary increased during upstream migration of pre-spawning chum salmon (Onuma et al., 2003b; Onuma et al., 2005b). We thus consider that a decline in the circulating IGF-I permit the increase in the activity of the HPG-axis toward the final maturation, or, secretion of IGF-I was repressed by the increase in the HPG-axis activity during upstream migration. The former possibility is supported by the fact that $\left[{ }^{125} \mathrm{I}\right] \mathrm{IGF}-\mathrm{I}$ infused into the cardiac artery of rats was delivered into the hypothalamus by crossing the blood brain-barrier (Reinhardt and Bondy, 1994). The latter possibility also exists because the plasma levels of androgens and estrogen in the present chum salmon peaked on the midway of the river prior to the decrease in the plasma IGF-I levels at the natal hatchery (Onuma et al., 2009a).

In conclusion, the plasma IGF-I levels increased in according with gonadal development when chum salmon are migrating from the winter Gulf of Alaska toward the summer Bering Sea. Circulating IGF-I from visceral organs may convey the information on stages of body growth to the PG-axis for initiation of gonadal development, and determine chum salmon whether to initiate spawning migration or not to home. Afterward, the plasma IGF-I levels are decreased with final maturation during upstream migration in the spawning period.

\section{Acknowledgments}

The authors thank our colleagues in Hokkaido University, Northwest Fisheries 
Science Center, Mr. H. Aihara (Atsuta fisherman’s cooperative association) and crews of R/V Wakatake-maru and Kaiyo-maru for their help in sampling of chum salmon. We appreciate Kathleen A. Cooper (Northwest Fisheries Science Center) for guidance of IGF-I radioimmunoassay. The present study was supported in part by the Grants-in-Aid from the Fisheries Agency and the Ministry of Education, Culture, Sports, Science and Technology, Japan. T.A.O. was supported by a research fellowship from the Japanese Society for the Promotion of Science for Young Scientists (No. 200409104 and 200609320). Ocean researches were supported in part by the Promotion Program for International Resources Surveys from the Fisheries Agency of Japan. 


\section{References}

Ando, H., Luo, Q., Koide, N., Okada, H., Urano, A., 2006. Effects of insulin-like growth factor I on GnRH-induced gonadotropin subunit gene expressions in masu salmon pituitary cells at different stages of sexual maturation. Gen. Comp. Endocrinol. 149, 21-29.

Baker, D. M., Davies, B., Dickhoff, W. W., Swanson, P., 2000. Insulin-like growth factor I increases follicle-stimulating hormone (FSH) content and gonadotropin-releasing hormone-stimulated FSH release from coho salmon pituitary cells in vitro. Biol. Reprod. 63, 865-871.

Beckman, B. R., Larsen, D. A., Moriyama, S., Lee-Pawlak, B., Dickhoff, W. W., 1998. Insulin-like growth factor-I and environmental modulation of growth during smoltification of spring chinook salmon (Oncorhynchus tshawystscha). Gen. Comp. Endocrinol. 109, 325-335.

Campbell, B., Dickey, J. T., Swanson, P., 2003. Endocrine changes during onset of puberty in male spring Chinook salmon, Oncorhynchus tshawytscha. Biol. Reprod. 69, 2109-2117.

Campbell, B., Dickey, J., Beckman, B., Young, G., Pierce, A., Fukada, H., Swanson, P., 2006. Previtellogenic oocyte growth in salmon: relationships among body growth, plasma insulin-like growth factor-1, estradiol-17beta, follicle-stimulating hormone and expression of ovarian genes for insulin-like growth factors, steroidogenic-acute regulatory protein and receptors for gonadotropins, growth hormone, and somatolactin. Biol. Reprod. 75, 34-44.

Duan, C. and Hirano, T., 1992. Effects of insulin-like growth factor-I and insulin on the 
in-vitro uptake of sulphate by eel branchial cartilage: Evidence for the presence of independent hepatic and pancreatic sulphation factors. J. Endocrinol. 133, 211-219.

Fukada, H., Ozaki, Y., Pierce, A. L., Adachi, S., Yamauchi, K., Hara, A., Swanson, P., Dickhoff, W. W., 2005. Identification of the salmon somatolactin receptor, a new member of the cytokine receptor family. Endocrinology 146, 2354-2361.

Furukuma, S., Onuma, T., Swanson, P., Luo, Q., Koide, N., Okada, H., Urano, A., and Ando, H., 2008. Stimulatory effects of insulin-like growth factor 1 on expression of gonadotropin subunit genes and release of follicle-stimulating hormone and luteinizing hormone in masu salmon pituitary cells early in gametogenesis. Zool. Sci. 25, 88-98.

Larsen, D. A., Shimizu, M., Cooper, K. A., Swanson, P., Dickhoff, W. W., 2004. Androgen effects on plasma GH, IGF-I, and 41-kDa IGFBP in coho salmon (Oncorhynchus kisutch). Gen. Comp. Endocrinol. 139, 29-37.

Le Gac, F., Loir, M., Le Bail, P. Y., Ollitrault, M., 1996. Insulin-like growth factor (IGF-I) mRNA and IGF-I receptor in trout testis and in isolated spermatogenic and Sertoli cells. Mol. Reprod. Dev. 44, 23-35.

Maestro, M. A., Planas, J. V., Moriyama, S., Gutierrez, J., Planas, J., Swanson, P., 1997. Ovarian receptors for insulin and insulin-like growth factor I (IGF-I) and effects of IGF-I on steroid production by isolated follicular layers of the preovulatory coho salmon ovarian follicle. Gen. Comp. Endocrinol. 106, 189-201.

McCormick, S. D., O'dea, M. F., Moeckel, A. M., Lerner, D. T., Bjornsson, B. T., 2005. Endocrine disruption of parr-smolt transformation and seawater tolerance of Atlantic salmon by 4-nonylphenol and 17beta-estradiol. Gen. Comp. Endocrinol. 142, 280-288. 
Morita, K. and Fukuwaka, M. A., 2006. Does size matter most? The effect of growth history on probabilistic reaction norm for salmon maturation. Evolution 60, 1516-1521.

Moriya, S., Sato, S., Azumaya, T., Suzuki, O., Urawa, S., Urano, A., Abe, S., 2007. Genetic stock identification of chum salmon in the bering sea and north pacific ocean using mitochondrial DNA microarray. Mar. Biotechnol. 9, 179-191.

Munakata, A., Amano, M., Ikuta, K., Kitamura, S., Aida, K., 2001. The involvement of sex steroid hormones in downstream and upstream migratory behavior of masu salmon. Comp.Biochem.Physiol.C 129, 661-669.

Onuma, T., Higashi, Y., Ando, H., Ban, M., Ueda, H., Urano, A., 2003a. Year-to-year differences in plasma levels of steroid hormones in pre-spawning chum salmon. Gen. Comp. Endocrinol. 133, 199-215.

Onuma, T., Kitahashi, T., Taniyama, S., Saito, D., Ando, H., Urano, A., 2003b. Changes in expression of genes encoding gonadotropin subunits and growth hormone/prolactin/somatolactin family hormones during final maturation and freshwater adaptation in prespawning chum salmon. Endocrine 20, 23-34.

Onuma, T., Ando, H., Koide, N., Okada, H., Urano, A., 2005a. Effects of salmon GnRH and sex steroid hormones on expression of genes encoding growth hormone/prolactin/somatolactin family hormones and a pituitary-specific transcription factor in masu salmon pituitary cells in vitro. Gen. Comp. Endocrinol. 143, 129-141.

Onuma, T., Higa, M., Ando, H., Ban, M., Urano, A., 2005b. Elevation of gene expression for salmon gonadotropin-releasing hormone in discrete brain loci of prespawning chum salmon during upstream migration. J. Neurobiol. 63, 126-145. 
Onuma, T. A., Ando, H., Koide, N., Okada, H., Urano, A., 2007. Reproductive stage-related effects of salmon GnRH and sex steroid hormones on expression of genes encoding fushi tarazu factor 1 homolog and estrogen receptor $\alpha$ in masu salmon pituitary cells in vitro. Gen. Comp. Endocrinol. 152, 64-72.

Onuma, T. A., Sato, S., Katsumata, H., Makino, K., Hu, W., Jodo, A., Davis, N. D., Dickey, J. T., Ban, M., Ando, H., Fukuwaka, M. A., Azumaya, T., Swanson, P., Urano, A., 2009a. Activity of the pituitary-gonadal axis is increased prior to the onset of spawning migration of chum salmon. J. Exp. Biol. 212, 56-70.

Onuma, T.A., Makino, K., Ban, M., Ando, H., Fukuwaka, M., Azumaya, T., Swanson, T., Urano, A., 2009b. Elevation of the plasma level of insulin-like growth factor-I with reproductive maturation prior to initiation of spawning migration of chum salmon. Ann. N.Y. Acad. Sci. 1163, 497-500.

Reinhardt, R.R., Bondy, C. A., 1994. Insulin-like growth factors cross the blood-brain barrier. Endocrinology 135, 1753-1761.

Sato, S., S. Takahashi, L.W. Seeb, J.E. Seeb, F. Fukuwaka, S. Urawa, 2006. Stock Identification of Winter Chum Salmon by mitochondrial DNA and SNP Analyses. NPAFC Doc. 963.

Sato, S., Azumaya, T., Urawa, S., 2007. Genetic stock identification of chum salmon in the summer Bering Sea 2004. NPAFC Technical Report 7, 66-68.

Shimizu, M., Swanson, P., Fukada, H., Hara, A., Dickhoff, W. W., 2000. Comparison of extraction methods and assay validation for salmon insulin-like growth factor-I using commercially available components. Gen. Comp. Endocrinol. 119, 26-36. 
Weil, C., Carre, F., Blaise, O., Breton, B., Le Bail, P. Y., 1999. Differential effect of insulin-like growth factor I on in vitro gonadotropin (I and II) and growth hormone secretions in rainbow trout (Oncorhynchus mykiss) at different stages of the reproductive cycle. Endocrinology 140, 2054-2062. 


\section{Figure legends}

Figure 1 Frequency distributions of the BW for chum salmon in the central Bering Sea, 2001-2003. The frequencies of BW were calculated from fish caught during summer (June and July, upper panel) and autumn (September, lower panel). Fitted curves were obtained by a Gaussian distribution with multiple peaks. The ages of fish were estimated from scales. Data collected during summer show a sizable component of fish with high BW, whereas fish with high BW are rather few in September.

Figure 2 The plasma IGF-I levels and the amounts of IGF-I mRNA in the livers of chum salmon in the winter Gulf of Alaska in 2006 and the summer Bering Sea in 2003. Sampling locations, the number of fish, and the criteria of immature and maturing adult I are shown in Onuma et al. (2009a). The data in our preliminary report (Onuma et al., 2009b) were used for comparison between the winter and summer chum salmon. Each value represents mean \pm standard error. Significant differences among groups are identified with different letters ( $\mathrm{p}<0.05$ one-way ANOVA and Tukey test).

Figure 3 Changes in the plasma IGF-I levels and the amounts of IGF-I mRNA in the livers of homing adults during upstream migration in 2001-2003. Pre-spawning and matured chum salmon were collected along their homing pathway from the coast to the hatchery. Fish near or at the hatchery almost completed final maturation, so that they were regarded as matured adults. Furthermore, data are compared with those from maturing I adults in the Bering Sea. Information on sampling locations and the number of fish are shown in Onuma et al. (2009a). Each value represents mean \pm standard error. Significant differences among sampling points are identified with different letters ( $p<0.05$ one-way ANOVA and Tukey test). 
Table 1 The plasma levels of IGF-I and the amounts of IGF-I mRNA in the livers of chum salmon in the central Bering Sea from 2001 to 2003 (mean \pm SEM). The samples are from the same fish used in our previous reports (Onuma et al., 2009a). The data in 2003 were presented in our preliminary report (Onuma et al., 2009b).

\begin{tabular}{|c|c|c|c|c|c|}
\hline Sex & Year & Months & Stage of gonads & $\begin{array}{c}\text { Plasma IGF-I levels } \\
(\mathrm{ng} / \mathrm{ml})\end{array}$ & $\begin{array}{c}\text { IGF-I mRNA } \\
\left(\times 10^{6} \text { copies } / \mu g \text { total RNA }\right)\end{array}$ \\
\hline \multirow{11}{*}{ Male } & \multirow{3}{*}{2001} & Jun.-Jul. & Immature & $33.5 \pm 2.8^{\mathrm{a}}$ & - \\
\hline & & - & Maturing adult I & $70.7 \pm 4.4^{\mathrm{b}}$ & - \\
\hline & & - & Maturing adult II & $100.7 \pm 11.1^{\mathrm{C}}$ & - \\
\hline & \multirow[t]{4}{*}{2002} & Jun.-Jul. & Immature & $41.0 \pm 2.2^{\mathrm{a}}$ & $1.96 \pm 0.20^{\mathrm{a}}$ \\
\hline & & & Maturing adult I & $87.4 \pm 6.6^{\mathrm{b}}$ & $2.48 \pm 0.29^{\mathrm{a}}$ \\
\hline & & - & Maturing adult II & $120.6 \pm 14.8^{\mathrm{c}}$ & $3.85 \pm 0.72^{b}$ \\
\hline & & Sep. & Immature & $19.0 \pm 1.1^{\mathrm{d}}$ & - \\
\hline & \multirow[t]{4}{*}{2003} & Jun.-Jul. & Immature & $34.4 \pm 2.0^{\mathrm{a}}$ & $1.58 \pm 0.20^{\mathrm{a}}$ \\
\hline & & - & Maturing adult I & $55.8 \pm 3.5^{\mathrm{b}}$ & $2.31 \pm 0.24^{\mathrm{ab}}$ \\
\hline & & - & Maturing adult II & $87.2 \pm 8.5^{\mathrm{c}}$ & $3.09 \pm 0.39^{b}$ \\
\hline & & Sep. & Immature & $14.8 \pm 1.2^{\mathrm{d}}$ & $2.20 \pm 0.26^{\mathrm{ab}}$ \\
\hline \multirow[t]{11}{*}{ Female } & \multirow[t]{3}{*}{2001} & Jun.-Jul. & Immature & $29.6 \pm 4.1^{\mathrm{a}}$ & - \\
\hline & & - & Maturing adult I & $65.1 \pm 5.1^{\mathrm{b}}$ & - \\
\hline & & - & Maturing adult II & $47.2 \pm 8.5^{\mathrm{ab}}$ & - \\
\hline & \multirow[t]{4}{*}{2002} & Jun.-Jul. & Immature & $34.0 \pm 1.7^{\mathrm{a}}$ & $1.81 \pm 0.20^{\mathrm{ab}}$ \\
\hline & & - & Maturing adult I & $79.1 \pm 3.5^{\mathrm{b}}$ & $2.53 \pm 0.31^{\mathrm{a}}$ \\
\hline & & - & Maturing adult II & $68.1 \pm 11.8^{\mathrm{b}}$ & $1.05 \pm 0.47^{\mathrm{b}}$ \\
\hline & & Sep. & Immature & $20.1 \pm 2.8^{\mathrm{a}}$ & - \\
\hline & \multirow[t]{4}{*}{2003} & Jun.-Jul. & Immature & $29.1 \pm 1.3^{\mathrm{ab}}$ & $1.84 \pm 0.18$ \\
\hline & & - & Maturing adult I & $56.8 \pm 4.4^{\mathrm{C}}$ & $2.07 \pm 0.19$ \\
\hline & & - & Maturing adult II & $39.7 \pm 8.3^{\mathrm{a}}$ & $1.23 \pm 0.38$ \\
\hline & & Sep. & Immature & $16.5 \pm 1.8^{\mathrm{b}}$ & $1.86 \pm 0.30$ \\
\hline
\end{tabular}

Fish were divided into immature fish, maturing adult I and II on the basis of histological inspection of gonads (Onuma et al., 2009a). Values with the different superscripts indicate significant difference within the same year $(p<0.05)$. 
Table 2 Correlation coefficients of the plasma levels of IGF-I and the amounts of IGF-I mRNA with parameters of activity of the PG-axis of chum salmon in the Bering Sea from June to July. ${ }^{*} P<0.05$, ${ }^{* * *} P<0.01$. The upper table shows relations within the same age group: upper value in each cell, 3-year-old fish ( $\mathrm{n}=20-40)$, and lower values, 4-year-old fish $(n=32-72)$. The lower table shows relations within the mitochondrial DNA haplotype clade: upper values, clade A, i.e., Japanese population ( $\mathrm{n}=20-40)$, and lower values, clade B, i.e., mixture of Japanese, Russian and North American populations ( $\mathrm{n}=32-72$ )

\begin{tabular}{|c|c|c|c|c|c|c|c|c|c|c|c|c|c|c|}
\hline & Parameter & $\begin{array}{l}\text { IGF-I } \\
\text { mRNA }\end{array}$ & BW & GSI & HSI & $\begin{array}{l}\text { Plasma } \\
\mathrm{T}\end{array}$ & $\begin{array}{l}\text { Plasma } \\
11 \mathrm{KT}\end{array}$ & $\begin{array}{l}\text { Plasma } \\
\text { E2 }\end{array}$ & $\begin{array}{l}\text { Plasma } \\
\text { FSH }\end{array}$ & $\begin{array}{l}\text { Pituitary } \\
\text { FSH }\end{array}$ & $\begin{array}{l}\text { Pituitary } \\
\text { LH }\end{array}$ & $\begin{array}{l}\alpha 2 \\
\text { mRNA }\end{array}$ & $\begin{array}{l}\text { FSH } \beta \\
\text { mRNA }\end{array}$ & $\begin{array}{l}\mathrm{LH} \beta \\
\text { mRNA }\end{array}$ \\
\hline \multirow[t]{4}{*}{ Males } & Plasma & $0.29 *$ & $0.76 * *$ & $0.63 * *$ & -0.17 & $0.65 * *$ & $0.48 * *$ & 0.02 & $0.63^{* *}$ & $0.70 * *$ & $0.54 * *$ & $0.32 * *$ & $0.30 * *$ & $0.25^{*}$ \\
\hline & IGF-I & $0.67 * *$ & $0.72 * *$ & $0.68 * *$ & $-0.69 * *$ & $0.63 * *$ & $0.76 * *$ & 0.13 & $0.79 * *$ & $0.76^{* *}$ & $0.53 * *$ & 0.31 & 0.21 & 0.19 \\
\hline & IGF-I & & $0.33 *$ & -0.07 & 0.17 & 0.06 & 0.04 & -0.11 & 0.10 & 0.07 & -0.04 & -0.06 & -0.05 & -0.13 \\
\hline & mRNA & & $0.56 *$ & 0.35 & $-0.43^{*}$ & 0.41 & $0.57 *$ & 0.25 & $0.49 *$ & 0.44 & 0.34 & 0.43 & 0.24 & 0.30 \\
\hline \multirow[t]{4}{*}{ Females } & Plasma & $0.42 * *$ & $0.68 * *$ & 0.08 & 0.09 & 0.17 & 0.06 & $0.36 * *$ & $0.51 * *$ & $0.37 *$ & 0.18 & $0.48 * *$ & $0.56 * *$ & $0.28 *$ \\
\hline & IGF-I & 0.21 & $0.52 * *$ & 0.20 & -0.13 & 0.29 & 0.42 & 0.27 & 0.33 & -0.04 & 0.39 & 0.16 & 0.10 & -0.13 \\
\hline & IGF-I & & 0.19 & -0.25 & 0.06 & -0.25 & -0.30 & 0.02 & 0.08 & -0.04 & -0.39 & 0.27 & 0.13 & 0.00 \\
\hline & mRNA & & 0.15 & -0.10 & 0.16 & -0.25 & 0.32 & -0.15 & 0.11 & 0.16 & -0.30 & 0.28 & 0.20 & -0.02 \\
\hline
\end{tabular}

\begin{tabular}{|c|c|c|c|c|c|c|c|c|c|c|c|c|c|c|}
\hline \multirow[t]{4}{*}{ Males } & Plasma & 0.38 & $0.74 * *$ & $0.75 * *$ & $-0.50 * *$ & $0.79 * *$ & $0.69 * *$ & 0.16 & $0.81^{* *}$ & $0.77 * *$ & $0.60 *$ & $0.48^{*}$ & $0.46 * *$ & 0.28 \\
\hline & IGF-I & $0.38 *$ & $0.77 * *$ & $0.59 * *$ & $-0.45 * *$ & $0.64^{* *}$ & $0.61^{* *}$ & 0.16 & $0.68 * *$ & $0.76 * *$ & $0.64 * *$ & $0.41^{* *}$ & $0.35 * *$ & $0.36 * *$ \\
\hline & IGF-I & & $0.51 *$ & 0.34 & -0.35 & 0.42 & 0.51 & 0.30 & 0.24 & $0.52 *$ & $0.58 *$ & 0.12 & 0.07 & 0.21 \\
\hline & mRNA & & $0.46 * *$ & -0.02 & 0.14 & 0.12 & 0.17 & -0.02 & 0.22 & 0.20 & 0.12 & 0.07 & 0.00 & 0.00 \\
\hline \multirow[t]{4}{*}{ Females } & Plasma & 0.38 & $0.68 * *$ & $0.58 * *$ & 0.14 & $0.68 * *$ & $0.73 * *$ & $0.62 * *$ & 0.21 & $0.74 * *$ & 0.42 & $0.55 * *$ & $0.49 * *$ & $0.40 * *$ \\
\hline & IGF-I & 0.28 & $0.61 * *$ & 0.16 & 0.01 & 0.21 & 0.03 & $0.29 *$ & $0.29 *$ & $0.42 *$ & $0.53 * *$ & $0.49 * *$ & $0.49 * *$ & 0.26 \\
\hline & IGF-I & & $0.47 *$ & 0.18 & 0.16 & 0.28 & 0.03 & 0.10 & 0.07 & 0.308 & 0.09 & $0.60 * *$ & $0.58 * *$ & 0.39 \\
\hline & mRNA & & 0.05 & -0.18 & 0.17 & -0.25 & -0.10 & -0.19 & -0.04 & -0.13 & -0.13 & 0.05 & -0.08 & -0.11 \\
\hline
\end{tabular}


June-July
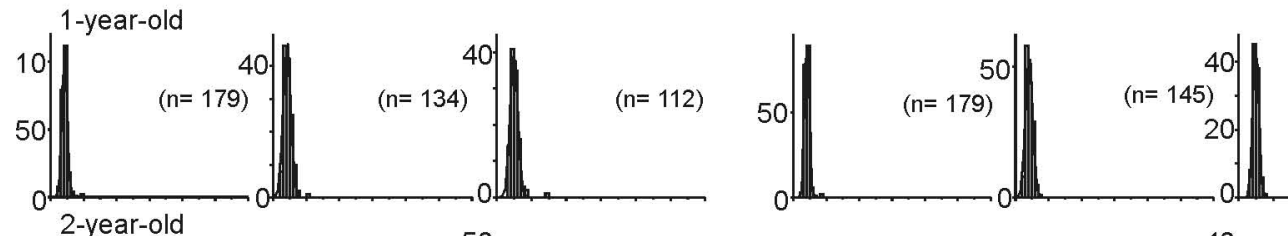

$(n=98)$
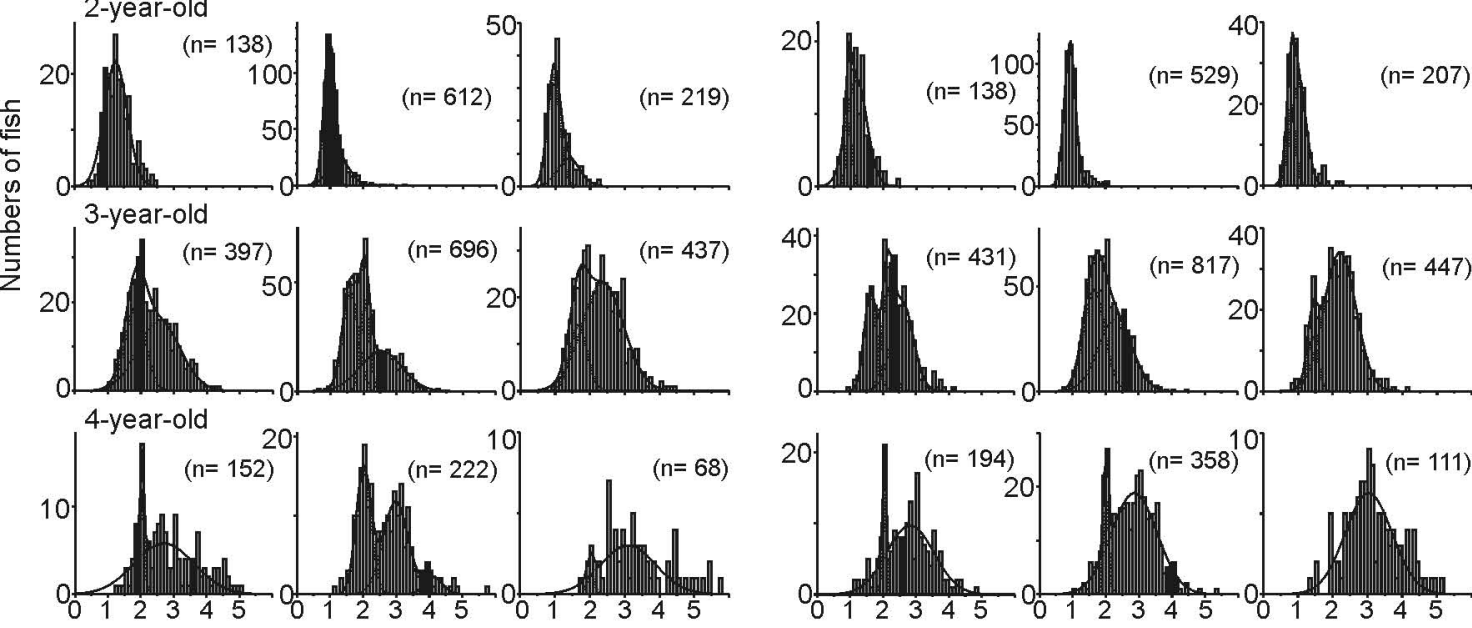

September
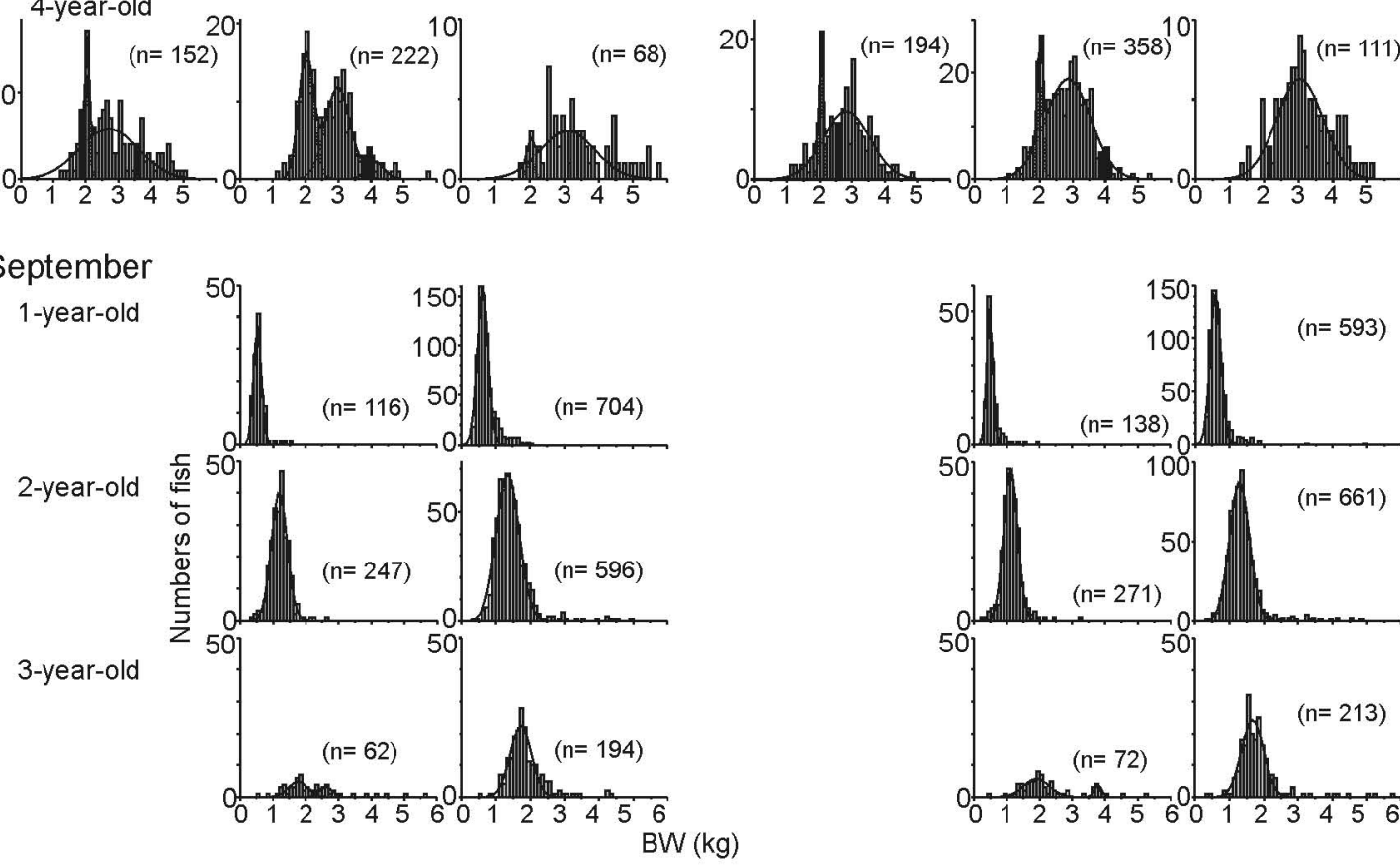

\section{Figure 1 \\ Onuma et al.}



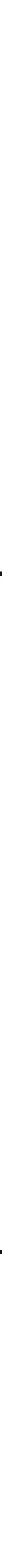

Figure 2

Onuma et al. 


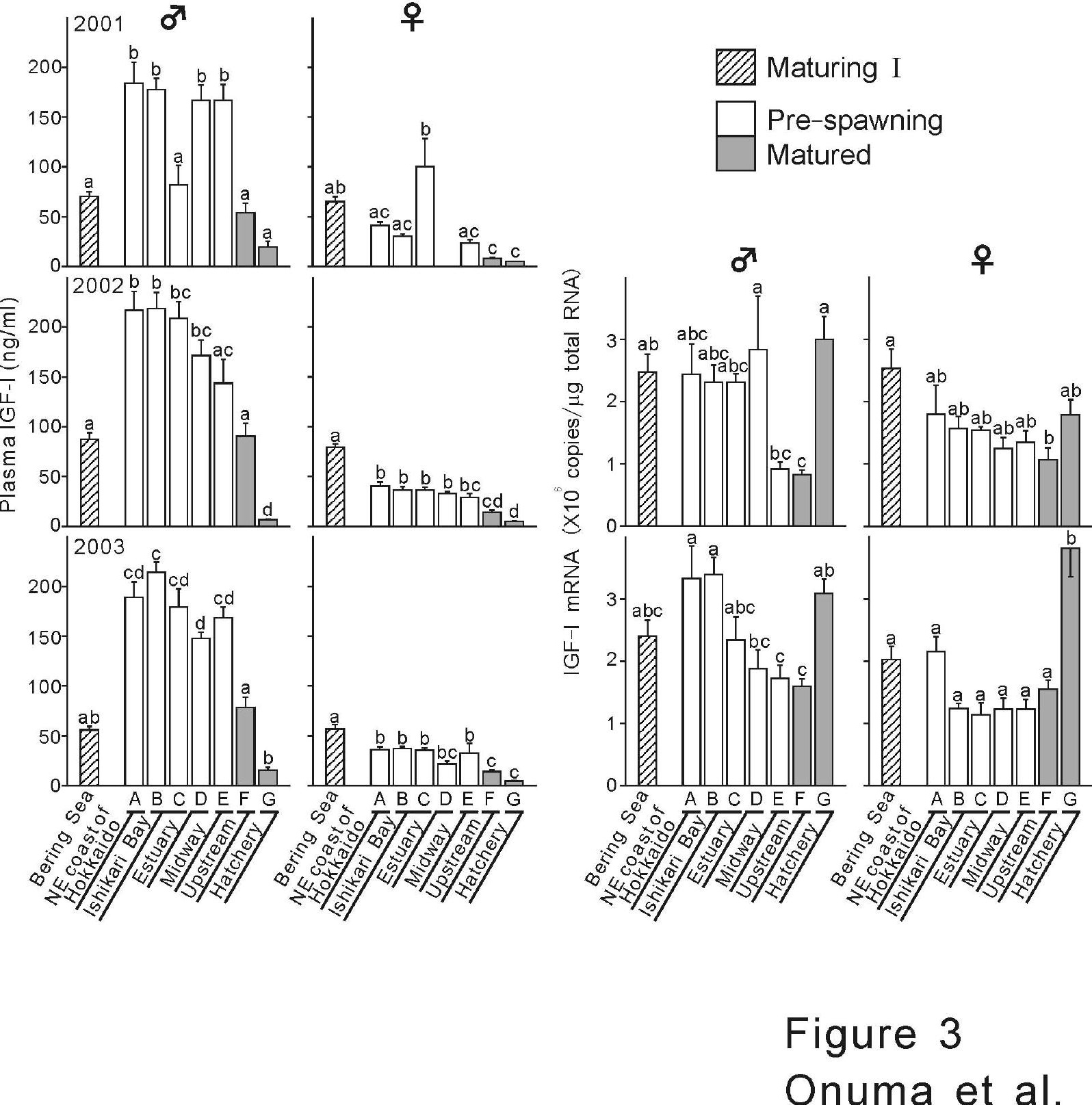

